\title{
Inspiracje Laudato si' do projektów z zakresu architektury krajobrazu miasta
}

\author{
Kasper Jakubowski \\ Wydział Architektury Politechniki Krakowskiej, \\ Instytut Architektury Krajobrazu (A-82), ul. Warszawska 24, 31-155 Kraków, pok. 308 \\ Ruch Ekologiczny św. Franciszka z Asyżu (REFA), kasper.jakubowski@gmail.com
}

\section{Streszczenie}

W pracy zaprezentowano własne badania nad treścią encykliki Laudato si' (LS) z punktu widzenia problematyki środowiskowej współczesnych miast i architektury krajobrazu. Encyklika Ojca Świętego stanowi inspirującą diagnozę i opis zjawisk, czerpiącą z osiągnięć i ustaleń różnych dziedzin nauki. W pracy sformułowano dziesięć głównych pól tematycznych z Laudato si', ważnych z punktu widzenia zrównoważonego rozwoju miast i projektów architektury krajobrazu. Głównym tematem encykliki jest współzależność pomiędzy środowiskiem przyrodniczym i społecznym. Przesłane, jakie płynie z zawartych w dokumencie analiz i wniosków, jest pozytywne: możliwe są inne scenariusze rozwoju i zasady kształtowania (a tam, gdzie to konieczne - odtwarzania) środowiska. Wskazano na propozycje zmian i praktycznych rozwiązań, inspirujących dla społecznej, ekologicznej, przestrzennej odnowy miast. Autor analizuje je na tle aktualnych tendencji w architekturze krajobrazu, której jednym z przyszłościowych kierunków jest renaturyzacja krajobrazu miejskiego.

\section{Stowa kluczowe}

park miejski, usługi ekosystemów, różnorodność biologiczna, udostępnienie, renaturyzacja

\section{Wprowadzenie}

Celem artykułu jest przybliżenie wielostronnych inspiracji, jakie płyną z encykliki Laudato si' w związku z aktualnymi tendencjami ekologicznymi w architekturze krajobrazu. Kwestia krajobrazu i ekologii miasta (urban ecology) znajduje interesujący punkt odniesienia w dokumencie papieskim zarówno w ujęciu teoretycznym, jak i praktycznym. Projektowanie i zakładanie przestrzeni publicznych, „łączących, ułatwiających relację, sprzyjających uznaniu drugiego człowieka" (LS: 150), jest domeną architektury krajobrazu. Nie do przecenienia są wkład i osiągnięcia innych dyscyplin naukowych, jak: urbanistyka, architektura, psychologia środowiskowa, socjologia, ekologia czy ekonomia. Kreowanie przestrzeni publicznych musi także uwzględniać rozwiązywanie problemów społecznych i środowiskowych oraz partycypację lokalnych społeczności w większym zakresie, niż to było w przeszłości. Dotyczy to przede wszystkim poprawy jakości życia, ochrony różnorodności biologicznej, adaptacji miast do zmian klimatu (climate change) i, last but not least, edukacji 
na rzecz zrównoważonego rozwoju. Liczne miasta w Europie i na świecie podjęły wiele pionierskich i przyszłościowych inicjatyw na tych polach (Jakubowski 2013a: 87-97). Odnosząc je do encykliki, choć „działania te nie rozwiązują problemów globalnych, ale potwierdzają, że człowiek jest jeszcze w stanie pozytywnie ingerować" (LS: 58 ). Wynikiem takiego myślenia są realizowane projekty w obszarach zurbanizowanych, m.in. w zakresie:

- rekultywacji terenów zdegradowanych, odtwarzania ekosystemów, renaturyzacji krajobrazu

- ochrony, a tam gdzie to konieczne przywracania korytarzy ekologicznych i łączenia izolowanych siedlisk

- kształtowania nowych i odzyskiwania powierzchni biologicznie czynnych w miastach, np. zielonych dachów, zieleni wertykalnej, ogrodów deszczowych

- ochrona przyrodniczej funkcji terenów nieurządzonych w mieście (np. nieużytków urbanistycznych) i ich adaptacja na przestrzenie publiczne

- ochrona terenów cennych przyrodniczo poprzez ich trwałe udostępnienie i stosowne przystosowania na potrzeby edukacji ekologicznej (np. poprzez centra edukacji ekologicznej)

- edukacja ekologiczna w miejskich terenach zieleni

- zakładania nowych terenów chronionych w granicach miasta i ochrona zagrożonych siedlisk przyrodniczych (np. podmokłych) także w zasięgu nowych zespołów zabudowy

- kształtowania ogólnodostępnych systemów terenów zieleni

- wdrażania prośrodowiskowych rozwiązań w zakładaniu i utrzymaniu terenów zieleni, np. zastępowanie trawników łąkami kwietnymi, wykorzystanie sukcesji ekologicznej w kreowaniu nowych parków, odtwarzanie zagrożonych siedlisk w miastach (np. mokradłowych, łęgowych czy łąkowych), wykorzystanie materiałów z recyklingu, ochrona lokalnych zasobów przyrodniczych (np. protegowanie rodzimej flory, ochrona lokalnej różnorodności genetycznej przez ochronę i sadzenie gatunków występujących in situ).

Cechą wymienionych wyżej działań jest także poszukiwanie nowej estetyki środowiskowej i uzasadnienia dla bardziej naturalnych rozwiązań w terenach zieleni, odmiennych od sztucznej, bezpiecznej, intensywnie utrzymywanej zieleni miejskiej. Na ile przyroda i ekosystemy zbliżone do naturalnych mogą stać się trwałym komponentem środowiska miejskiego, zyskując większą akceptację mieszkańców? Jak zwiększać świadomość korzyści, jakie oferują cenne przyrodniczo tereny zamieszkującym w ich sąsiedztwie społecznościom (tzw. usług ekosystemu)? Jakie praktyczne inspiracje wnosi encyklika Laudato si' do współczesnej architektury krajobrazu oraz gdzie szukać inspirujących rozwiązań dla miast w obliczu opisanych w niej problemów społeczno-środowiskowych? Dla niniejszej rozprawy szczególnie interesujące jest pojęcie ekologii integralnej, tj. postrzeganie problemów ekologicznych w określonym kontekście społecznym. Ciekawa w tym ujęciu może być próba koegzystencji człowieka i przyrody także w jej stosunkowo mało przetworzonej postaci, właściwa niektórym nowym tendencjom urbanistyczno-architektonicznym. Doniosły jest także udział idei zrównoważonego rozwoju (sustainable development) w powstawaniu osiedli mieszkaniowych i projektów pod koniec lat 9o. XX wieku oraz na początku XXI wieku, stanowiących podłoże nowych koncepcji i rozwiązań w architekturze krajobrazu. I tak np. Greenwich Millennium Village (200o), Londom Wetland Centre (200o), Park Olimpijski Królowej Elżbiety (2012) - w Londynie; park natury Schöneberger Südgelände (1999), Park am Gleisdreieck (2008, 2012) - Berlin; Park van Luna - Herhugowaard (Holandia, 2007), Westergasfabriek - Amsterdam (2002); Eco -Quartier Clichy-Batignolles - Paryż (2015), 
czy osiągnięcia chińskiej pracownii Turenscape na świecie.

\section{Ekologiczne tendencje w projektowaniu. Powrót natury do miast?}

W XXI wieku coraz większą rolę odgrywają prośrodowiskowe rozwiązania projektowe terenów zieleni, gdzie udało się przywrócić zdegradowane siedliska, odtworzyć sieć ekologicznych połączeń między izolowanymi obszarami, zwiększyć lokalnie różnorodność biologiczną i zmienić nastawienie lokalnej społeczności do swojego habitat. Współcześnie w projektowaniu większy nacisk kładzie się na obecność naturalnych siedlisk w miastach. Tendencja do zakładania „parków ekologicznych” (ecological parks) i nowych powierzchni biologicznie czynnych (zielonych dachów, ogrodów wertykalnych) stopniowo przenika do polskich miast. W miarę jej wzrastania należy zadbać o wysoki poziom projektowania, niezbędną infrastrukturę, adekwatną estetykę rozwiązań przestrzennych czy monitoring oczekiwanych zmian w środowisku. Architektura krajobrazu, zgodnie z klasyczną definicją zaproponowaną przez Ch. T. Eliota na początku ubiegłego stulecia, to przede wszystkim sztuka kształtowania piękna w otoczeniu ludzkich siedzib (Böhm, Zachariasz 2005: 40). Druga połowa XX wieku jest okresem rosnącej świadomości kosztów środowiskowych i społecznych cywilizacyjnego rozwoju oraz nabierania przekonania o konieczności przeciwdziałania zanieczyszczeniom i degradującym ingerencjom w środowisku przyrodniczym. Punktem zwrotnym w architekturze krajobrazu okazały się lata 90., a szczególnie Szczyt Ziemi w Rio (1992) oraz ratyfikacja konwencji o różnorodności biologicznej i zmianach klimatu. Ta cezura czasowa oznaczała nowe strategie działań i rozwiązań na poziomie lokalnym na rzecz zrównoważonego rozwoju. W wyniku badań nad klimatem oraz zainteresowania społecznego i politycznego kryzysem ekologicznym zaczęły powstawać alternatywne koncepcje parków, tzw. parki nowej generacji. Przyświecają im takie cele jak ekologia, edukacja ekologiczna, dbałość o poprawę jakości życia, czy działania naprawcze w środowisku. Dużym osiągnięciem ogólnoeuropejskim są parki zakładane na terenach poprzemysłowych, gdzie przywraca się biologiczne funkcje, inicjuje regeneracje tych terenów oraz chroni florę kolonizującą industrialne destrukty (np. dawna huta Zollverein w Essen - obiekt UNESCO). Bardzo ważna jest świadomość, że oprócz ochrony terenów cennych przyrodniczo w granicach miasta konieczna jest polityka i wizja renaturyzacji zniszczonych fragmentów środowiska przyrodniczego. Przeciwieństwem komercjalizacji i urbanizacji terenów poprzemysłowych może być twórcze wykorzystanie ich zasobu przyrodniczego i kulturowego. Jak na przykład w Duisburg-Nord Park, gdzie zachowano i konserwuje się industrialne obiekty, w części adaptując je do nowych funkcji rekreacyjno-wystawienniczych, w części pozostawiając kolonizującej je przyrodzie. Polityka zakładania parków krajobrazowych na podłożu przemysłowym i cieków wodnych znalazła uzasadnienie także w przypadku nieczynnych kompleksów przemysłowo-wydobywczych w Zagłębiu Ruhry (np. park Emscher). W wyniku zaniechania dotychczasowych funkcji społecznogospodarczych samoistnie rozpoczyna się proces sukcesji ekologicznej, tworząc zbiorowiska roślinne niespotykane w naturze. Niektórzy badacze wskazują na niedoszacowaną wartość tej kategorii przyrody - „industrialnej”, powstającej na przekształconym siedlisku. Zbiorowiska te, charakterystyczne dla nieużytków urbanistycznych, należą do najlepiej zaadaptowanych do ekstremalnych, zmieniających się warunków miejskich. Często stanowią jedyne zwarte, rozrośnięte płaty zieleni wysokiej w otoczeniu zespołów zabudowy, bogate w chronione gatunki (np. tereny pokolejowe w Berlinie). Przykładem mogą być nowe parki europejskie zakładane na nieczynnych lotniskach, torowiskach, nieużytkach miejskich, w nieczynnych wyrobiskach i kamieniołomach (Jakubowski 2015: 145-162). Kontrowersyjnym zagadnieniem jest ich nieuporządkowany, 
niezorganizowany charakter, odbiegający od urządzonej, utrzymanej zieleni miejskiej. Wyzwaniem dla architektów krajobrazu jest nadanie im nowej formy estetycznej, udostępnienie, ergo wykorzystanie potencjału zieleni istniejącej, powstałej bez udziału człowieka roślinności, z zachowaniem autentyzmu przestrzeni. Interesujący kierunek stanowi także integracja urządzonych części parków (a przez to bogato wyposażonych) z częściami nieurządzonymi, gdzie funkcje społeczne i ekologiczne mogą się przenikać, uzupełniać, jak np. intensywna rekreacja z wydzieleniem fragmentów bez ingerencji i z ograniczoną obecnością człowieka (Park Olimpijski w Londynie). Pozytywne jest również przywracanie skanalizowanym odcinkom rzek w części ich naturalnego przebiegu i zbiorowisk łęgowych, jak w Sutcliffe Park w Londynie, oraz odtworzenie terenów bioretencyjnych w sąsiedztwie. Wokół takich zrenaturyzowanych parków powstają nowe zespoły urbanistyczne, a półdzika roślinność i obecność siedlisk mokradłowych udostępnionych do zwiedzania stanowią uzupełnienie bogatego programu terenów zieleni urządzonej dzielnic i osiedli (Hopkins 2012: passim).

Zakładanie nowych parków na zdegradowanych terenach miejskich i podmiejskich jest jednym z przyszłościowych kierunków oraz pozytywnych przykładów ingerencji w krajobraz. Rozwiązania te nie mogą być jednak alternatywą dla zachowania terenów cennych przyrodniczo oraz istniejących korytarzy ekologicznych, ponieważ wiele zmian zachodzących w środowisku przyrodniczym jest w istocie nieodwracalnych. Od początku XXI wieku wzrasta rola parków i systemów terenów zieleni miejskiej w poszukiwaniu równowagi ekologicznej w miastach podlegających dynamicznym przeobrażeniom. Parki kształtowane na terenach zdegradowanych, poprzemysłowych odbiegają od rozwiązań tradycyjnych z przeszłości. Współcześnie park pełni rozmaite funkcje ekologiczne i edukacyjne, pozostając obiektem (dziełem) o wysokich walorach estetycznych. Cechuje go różnorodność rozwiązań formalnych, wielowątkowość i rozmaitość środków wyrazu. Jak zaznacza A. Zachariasz, park miejski jest czynnikiem miastotwórczym i jednym z najważniejszych mierników jakości przestrzeni miejskiej, wspomagającym i współtworzącym wraz z terenami chronionymi system przyrodniczy miasta, określany dzisiaj nowym pojęciem zielonej infrastruktury (green infrastructure) (Zachariasz 2014: 59-65, 70-71, 82-83). Tym samym park pozostaje szczególną odmianą przestrzeni publicznej, kształtowaną z myślą o potrzebie rekreacji, kontaktu z naturą, obcowania z jej pięknem. Dla przeważającej części mieszkańców codziennym środowiskiem życia są obszary zurbanizowane, w tym mniejsze i większe ośrodki miejskie. Parki i tereny chronione w miastach mogą być więc miejscem do aktywnej edukacji ekologicznej opartej na stosownej infrastrukturze i nośnikach multimedialnych, a dzięki temu uwrażliwiać na piękno przyrody nawet w przypadku intensywnie zurbanizowanej przestrzeni, zwiększając świadomość o zagrożeniach i korzyściach, aktywizując mieszkańców, kształtując styl życia, ułatwiając kontakt z naturą na co dzień (Jakubowski 2015a: 34-36).

\section{Luadato si': miasta w obliczu wyzwań środowiskowych i społecznych}

Architekt krajobrazu może odnaleźć w encyklice Ojca Świętego wiele inspiracji i pogłębionych etycznie uzasadnień wprowadzania zmian przestrzennych w życie miasta (Jakubowski 2016: passim). Istotna jest także diagnoza oraz krytyczna refleksja, na ile sposób projektowania i planowania krajobrazu może realnie wpłynąć na poprawę stanu środowiska przyrodniczego i społecznego oraz jaki tu może być wkład innych dziedzin nauki i osiągnięć techniki. Architekt krajobrazu może być animatorem zmian, ukierunkowując je i nadając im realistyczną formę projektową w określonej przestrzeni, szukając partnerów w społecznościach lokalnych, we współpracy z organizacjami pozarządowymi. W tabeli ujęto dziesięć głównych pól tematycznych traktowanych jako wyzwania, 


\section{Tabela 1. Istotne tematy w Laudato si' z punktu widzenia architektury krajobrazu miasta}

\begin{tabular}{|c|c|}
\hline Wyzwania & Stanowisko LS - propozycje alternatywnych rozwiązań i zmian \\
\hline $\begin{array}{l}\text { W1: Zanik } \\
\text { bioróżnorodności }\end{array}$ & $\begin{array}{l}\text { - opracowanie pełnej analizy oddziaływania projektowanych inwestycji na lokalnie występującą } \\
\text { różnorodność biologiczną (nie tylko na glebę, wodę i powietrze) (35) } \\
\text { - tworzenie korytarzy biologicznych (ekologicznych), umożliwiających populacjom zwierząt migracje } \\
\text { i swobodne poruszanie się pomimo dzielących obszary dróg, ogrodzeń i innych barier (35) } \\
\text { - ochrona możliwie wszystkich organizmów, również grzybów, glonów, owadów, gadów } \\
\text { i mikroorganizmów (np. w glebie), w tym „gatunków, których zwykle się nie zauważa” (34) } \\
\text { - zmniejszenie ingerencji (interwencji) w naturalne procesy i funkcjonowanie ekosystemów (34) } \\
\text { - ochrona dzikiej flory (np. łąkowej) i konieczność opracowywania odpowiednich analiz } \\
\text { weryfikujących zasadność zastąpienia jej np. zadrzewionymi obszarami leśnymi (monokulturami) } \\
\text { (39) } \\
\text { - zabezpieczanie miejsc, obszarów niedostatecznie chronionych, istotnych z punktu widzenia } \\
\text { różnorodności biologicznej (biodiversity hotspots) (37) } \\
\text { - ochrona obszarów podmokłych (39) } \\
\text { - inwestycje w badania w zakresie funkcjonowania ekosystemów miejskich i skutków modyfikacji } \\
\text { środowiska (42) }\end{array}$ \\
\hline W2: Zmiany klimatu & $\begin{array}{l}\text { - redukcja emisji } \mathrm{CO}_{2} \text { i innych zanieczyszczających gazów przez „drastyczne” zmniejszenie zużycia } \\
\text { paliw kopalnych (26) } \\
\text { - rozwój odnawialnych źródeł energii (26) } \\
\text { - dostosowanie się (adaptacja) do skutków zmian klimatu (25) } \\
\text { - zmiana sposobów budowania i przebudowy budynków w celu zmniejszenia zużycia energii } \\
\text { i surowców (26) } \\
\text { - rozpowszechnianie dobrych praktyk w zakresie energooszczędności, ograniczenia zużycia } \\
\text { surowców, recyklingu materiałów (26) }\end{array}$ \\
\hline $\begin{array}{l}\text { W3: Kontakt z naturą } \\
\text { w mieście }\end{array}$ & $\begin{array}{l}\text { - zwiększanie dostępu do terenów zieleni i ułatwianie mieszkańcom kontaktu z przyrodą (44) } \\
\text { - przeciwdziałanie prywatyzacji zasobów przyrodniczych, powstawaniu zamkniętych osiedli, } \\
\text { wygrodzonych terenów zieleni (45) } \\
\text { - rozwój ogólnodostępnych terenów zieleni w dzielnicach dotkniętych problemami społecznymi } \\
\text { (46) }\end{array}$ \\
\hline $\begin{array}{l}\text { W4: Edukacja } \\
\text { ekologiczna }\end{array}$ & $\begin{array}{l}\text { - edukacja w zakresie oszczędności wody i skutków jej zanieczyszczania (29) } \\
\text { - wspieranie edukacji (wychowania) estetycznej jako warunku sine qua non utrzymania zdrowego } \\
\text { środowiska przyrodniczego (215) } \\
\text { - wychowanie do odpowiedzialności m.in. w zakresie ostrożnego, zachowawczego, pełnego } \\
\text { szacunku podejścia do innych istot żywych (211) } \\
\text { - wspieranie rodzin i tworzenie dla nich warunków do edukacji ekologicznej w miastach (213) } \\
\text { - protegowanie postawy „minimalizmu ekologicznego", ograniczanie nadmiernej ingerencji } \\
\text { w lokalny ekosystem, odkrywanie przyjemności w kontakcie z naturą (223) } \\
\text { - tworzenie zielonych enklaw ciszy i regeneracji nawet w obrębie najbardziej zatłoczonych } \\
\text { metropolii, gdzie ludzie mogą odzyskać spokój, harmonię ze stworzeniem i kontemplować } \\
\text { Stwórcę obecnego w tym, co ich otacza (225) }\end{array}$ \\
\hline $\begin{array}{l}\text { W5: Ochrona } \\
\text { krajobrazu }\end{array}$ & $\begin{array}{l}\text { - zapobieganie niekontrolowanemu i przesadnemu rozrostowi miast (urbanizacja), chaosowi } \\
\text { miejskiemu, skażeniu wizualnemu (44) } \\
\text { - ochrona dziedzictwa historycznego, artystycznego, kulturowego jako elementu tożsamości miasta } \\
\text { (143) } \\
\text { - zachowanie architektury w danym miejscu, warunkującej jego oryginalną tożsamość (143) } \\
\text { - zachowanie dominant widokowych, charakterystycznych ujęć widokowych, przestrzeni wspólnych } \\
\text { w mieście jako elementów jego genius loci (151) } \\
\text { - ingerencja w krajobraz miejski musi uwzględniać, że poszczególne elementy miejsca tworzą } \\
\text { pewną całość postrzeganą przez mieszkańców i pełną znaczeń (151) } \\
\text { - zachowanie przestrzeni bez ingerencji i nieustannych zmian w krajobrazie (151) }\end{array}$ \\
\hline
\end{tabular}


Tabela 1. Ciąg dalszy

\begin{tabular}{|c|c|}
\hline Wyzwania & Stanowisko LS - propozycje alternatywnych rozwiązań i zmian \\
\hline $\begin{array}{l}\text { W6: Kształtowanie } \\
\text { przestrzeni publicznych }\end{array}$ & $\begin{array}{l}\text { - integracja (nie izolacja) różnych części miasta, zachęcająca mieszkańców do partycypacji w życiu } \\
\text { dzielnic i całego miasta (49, 151) } \\
\text { - nacisk na dobro wspólne i powszechne przeznaczenia dóbr - społeczna funkcja jest nadrzędna } \\
\text { w stosunku do własności prywatnej (93) } \\
\text { - wykorzystanie osiągnięć techniki, nauki, sztuki w kształtowaniu przestrzeni publicznych (102) } \\
\text { - uwzględnienie integracyjnej funkcji przyrody i miejsc publicznych, wokół których powstają nowe } \\
\text { wspólnotowe działania i tworzy się lokalna tkanka społeczna (232) } \\
\text { - uwzględnienie w planach architektonicznych „przestrzeni łączących", ułatwiających relacje } \\
\text { społeczne, sprzyjających akceptacji drugiego człowieka (152) }\end{array}$ \\
\hline $\begin{array}{l}\text { W7: Interdyscyplinar- } \\
\text { ne podejście }\end{array}$ & $\begin{array}{l}\text { - uwzględnienie wkładu i osiągnięć innych dyscyplin wiedzy w projektowaniu i planowaniu } \\
\text { urbanistycznym (150) } \\
\text { - uwzględnienie w projektowaniu innych kryteriów niż tylko estetyczne, jak: harmonia ze } \\
\text { środowiskiem, jakość życia, integracja mieszkańców (150) }\end{array}$ \\
\hline $\begin{array}{l}\text { W8: Partycypacja } \\
\text { społeczna }\end{array}$ & $\begin{array}{l}\text { - uwzględnienie wkładu lokalnych społeczności w projektowaniu urbanistycznym (150) } \\
\text { - większa rola lokalnych organizacji, stowarzyszeń mieszkańców i oddolnych inicjatyw w procesie } \\
\text { decyzyjnym i planowaniu urbanistycznym (179) } \\
\text { - większa presja mieszkańców i instytucji na decydentów, kadry urzędnicze, przedsiębiorców } \\
\text { w sprawach dotyczących dobra wspólnego, środowiska, przestrzeni publicznych, jakości życia (180) } \\
\text { - w debatach na temat projektów uprzywilejowana rola mieszkańców danego miejsca (183) } \\
\text { - pełny dostęp do informacji o wszystkich aspektach, zagrożeniach, możliwościach na każdym } \\
\text { etapie projektu, także kontroli i monitoringu (183) }\end{array}$ \\
\hline $\begin{array}{l}\text { W9: Uwarunkowania } \\
\text { prawne, } \\
\text { transparentność } \\
\text { procesów decyzyjnych, } \\
\text { rozwiązywanie } \\
\text { konfliktów o przestrzeń }\end{array}$ & $\begin{array}{l}\text { - stworzenie systemu prawnego, regulacji, ograniczeń zapewniających skuteczną ochronę } \\
\text { ekosystemów (54) } \\
\text { - struktura polityczna i instytucjonalna ma zapobiegać złym praktykom, ale też aktywnie zachęcać } \\
\text { do dobrych praktyk, pobudzać kreatywność, poszukiwać nowych dróg do ułatwienia inicjatyw } \\
\text { osobistych i zbiorowych (177) } \\
\text { - uchwalanie prawa "ustanawiającego reguły dopuszczalnych zachowań w świetle dobra } \\
\text { wspólnego" (177-178) zgodnie z zasadą, że „środowisko przyrodnicze jest dobrem publicznym” } \\
\text { (95, 178) } \\
\text { - powiązanie analizy problemów środowiskowych z analizą wszystkich uwarunkowań, w tym } \\
\text { społecznych (pracy, rodziny, stosunków międzyludzkich) i kontekstu urbanistycznego (141) } \\
\text { - „pogłębiona” dyskusja o rzeczywistym wpływie danego projektu na środowisko, z udziałem } \\
\text { wszystkich zainteresowanych stron (stake holders) (182) } \\
\text { - studium oddziaływania na środowisko opracowane w sposób interdyscyplinarny, kompleksowy, } \\
\text { transparentny, wolny od jakiejkolwiek presji politycznej i gospodarczej (183) } \\
\text { - w przypadku inwestycji ingerujących w dobro wspólne, przestrzeń publiczną, środowisko- } \\
\text { konieczność przeprowadzenia obiektywnego bilansu zysków i strat, także z uwzględnieniem } \\
\text { innych możliwości (184) } \\
\text { - wobec prognozowanych negatywnych skutków w środowisku i dla jakości życia projekt powinien } \\
\text { być zaniechany lub zmieniony ( „rentowność nie może być jedynym kryterium”) (185-187) } \\
\text { - w przypadku pojawienia się nowych informacji na temat projektu konieczna ponowna jego ocena } \\
\text { z udziałem wszystkich zainteresowanych stron (187) } \\
\text { - wynikiem debaty „może być decyzja, by nie rozwijać projektu, ale także jego modyfikacja lub } \\
\text { opracowanie propozycji alternatywnych” (187) }\end{array}$ \\
\hline
\end{tabular}


Tabela 1. Ciąg dalszy

\begin{tabular}{|c|c|}
\hline Wyzwania & Stanowisko LS - propozycje alternatywnych rozwiązań i zmian \\
\hline $\begin{array}{l}\text { W10: Zrównoważony } \\
\text { rozwój miasta }\end{array}$ & $\begin{array}{l}\text { - ocena „prawdziwego rozwoju” (a nie jedynie rozrostu) miast - kryteria: na ile dochodzi do } \\
\text { integralnej poprawy jakości życia; narzędzia: interdyscyplinarna analiza przestrzeni, w której żyją } \\
\text { ludzie (147) } \\
\text { - szerokie, odpowiedzialne, dalekowzroczne spojrzenie zgodne z zasadą solidarności ogólnoludzkiej } \\
\text { i międzygeneracyjnej (159-162) } \\
\text { - podejmowanie ambitnych, „wielkich” celów i skuteczne wdrażanie „wielkich strategii” ochrony } \\
\text { środowiska i poprawy jakości życia (181), promujących w społeczeństwie „kulturę troski” (231) } \\
\text { - praktyczna, skuteczna, możliwie szybka realizacja międzynarodowych umów, porozumień, } \\
\text { konwencji w aspekcie ochrony środowiska przyrodniczego i klimatu (167) } \\
\text { - „wszechstronne” rozwijanie i postęp w produkcji odnawialnych, niskoemisyjnych form energii, } \\
\text { promowanie większej efektywności energetycznej (58, 164-165), stopniowe zastępowanie } \\
\text { technologii polegających na spalaniu paliw kopalnych (165) } \\
\text { - rozwój i prymat transportu publicznego (58, 153) } \\
\text { - ograniczenie ruchu samochodowego i nadrozwoju towarzyszącej mu infrastruktury drogowej (153) } \\
\text { - oszczędne użytkowanie wody (44), poprawa jakości wód powierzchniowych (29) } \\
\text { - planowanie i rozwój zrównoważonych, zróżnicowanych form rolnictwa (164) } \\
\text { - zrównoważone gospodarowanie środowiskiem, uwzględniające „zdolności każdego ekosystemu } \\
\text { do regeneracji w jego różnych obszarach i aspektach” (140) } \\
\text { - lepsze zarządzanie zasobami przyrodniczymi (165) } \\
\text { - rozwijanie pozytywnych form ingerencji w środowisko przyrodnicze w zakresie m.in.: rekultywacjii, } \\
\text { poprawy stanu środowiska, „upiększania krajobrazu”, estetyki projektów architektonicznych (58) } \\
\text { - monitoring stanu środowiska przyrodniczego (167, 177, 183) }\end{array}$ \\
\hline
\end{tabular}

wobec jakich stają współczesne miasta. Następnie z perspektywy encykliki sformułowano propozycje zmian, priorytetowe kierunki rozwoju istotne z punktu widzenia architektury krajobrazu. Różne elementy encykliki mogą stanowić wielowątkową inspirację także w warunkach polskich miast, m.in. roli partycypacji społecznej, zrównoważonych projektów urbanistycznych, eliminowania tzw. zamkniętych osiedli czy przeciwdziałania "skażeniu wizualnemu” krajobrazu. Ojciec Święty proponuje także interesujące podejście do rozwiązywania konfliktów społecznych związanych z oddziaływaniem przedsięwzięć na środowisko przyrodnicze, co w Polsce wciąż jeszcze stanowi novum. Dużą wagę przykłada do praktycznych rozwiązań i inicjowania pozytywnych procesów zmiany, pomimo że rezultaty wymagają czasu, a efekty nie są często spektakularne. Można sam dokument czytać jako nieustanną zachętę ponaglającą do aktywności: „wiele można zrobić!” (LS: 180) i uważności: „rzeczywistość jest ważniejsza od idei” (LS: 203). A jak przeczytamy w dokumencie programowym pontyfikatu Evangelii gaudium: „Pociąga to za sobą unikanie różnych form ukrywania rzeczywistości: angelicznych puryzmów, dyktatury relatywizmów, pustej retoryki, projektów bardziej formalnych niż realnych [...] Idee jako opracowania konceptualne służą postrzeganiu, zrozumieniu i kierowaniu rzeczywistością. Idea oderwana od rzeczywistości rodzi nieskuteczne idealizmy i nominalizmy, które w najlepszym razie klasyfikują i definiują, ale nie angażują. To, co angażuje, to rzeczywistość oświecona rozumowaniem" (Ojciec Święty Franciszek 2013: 231-232).

Przestrzeń miejska jest niewątpliwie zasobem i jako taki wymaga ochrony przed degradującymi, krótkowzrocznymi decyzjami naruszającymi funkcjonowanie ekosystemów miejskich, pogarszającymi stan środowiska przyrodniczego w przyszłości, a w konsekwencji negatywnie oddziałującymi na krajobraz („wizualne skażenie miast” - LS: 44). Wiele działań podejmowanych przez władze lokalne i przedsiębiorców inwestycyjnych narusza różnorodność biologiczną, 
lokalne uwarunkowania przyrodnicze, stoi w sprzeczności z dobrem wspólnym obecnych i przyszłych mieszkańców (solidarność międzygeneracyjna). Papież przypomina, że „środowisko jest dobrem publicznym [...] Ten, kto posiada jego część, ma ją jedynie po to, aby zarządzać nią dla dobra wszystkich” (LS: 95). Prywatyzacja zasobów, w tym przestrzeni, i ich degradacja bądź uszczuplenie przyczyniają się do pogorszenia jakości życia na wielu poziomach. Negatywnymi przykładami mogą być ograniczony dostęp do terenów zieleni w mieście w wielu nowych dzielnicach, zabudowa korytarzy przewietrzania miasta, zjawisko grodzenia osiedli czy degradacja więzi społecznych (sąsiedzkich), gentryfikacja czy utrata genius loci, a więc i emocjonalnej więzi z miejscem zamieszkania. Takiej unifikacji i utraty swojskości, czy za K. Pawłowską „lokalności” miejsca, papież dopatruje się w formie współczesnej architektury. „Jeśli architektura odzwierciedla ducha epoki, to megastruktury i seryjne domy wyrażają ducha zglobalizowanej techniki, w której nieustanna nowość produktów łączy się z ciążącą nudą". Można także przywołać próby zastępowania przyrody jej kiczowatą namiastką (tzw. „trywializacja przyrody"), stanowiące symbol bezguścia, a nie troski o jakość przestrzeni miejskiej. Podobnie zamienia się złożone układy przyrodnicze w uproszczone struktury, sztucznie podtrzymywane przy życiu za pomocą skomplikowanych zabiegów. Wiele siedlisk w miastach ulega degradacji poprzez ich upraszczanie, nadmierną pielęgnację, zastępowanie florą bez związku z siedliskiem, gatunkami obcymi. Tymczasem warto tu przywołać intuicję św. Franciszka z Asyżu, „pierwszego ekologa”, i jego postulat pozostawiania „nieuprawnego obrzeża”, gdzie przyroda może się rozwijać według własnej logiki, bez przesadnej ingerencji człowieka. Postulat ten może znaleźć nowe uzasadnienie w projektach architektury krajobrazu, które na części terenów zapewniają miejsca dla spontanicznych procesów przyrodniczych, aby następnie można je było poznawać i obserwować. Jak piszą P. Pawlaczyk,
A. Jermaczek, istotna jest funkcja refugiów w krajobrazie dla fauny i flory: „zabezpieczenie (odpowiednio wybranych) 15\% terenu zabezpiecza byt $85 \%$ gatunków na tym terenie występujących" (Pawlaczyk, Jermaczek 2009: 95). Bezpieczeństwo siedlisk przyrodniczych znajduje także niebanalne uzasadnienie w ochronie rozległych terenów niezurbanizowanych w granicach miast (Londyn) oraz jako składnik nowych zespołów urbanistycznych (np. Szlak Dróg Kolejowych w Monachium czy Gleisdreieck w Berlinie).

Potrzeba nowych zasad koegzystencji człowieka z przyrodą, aby wymagania środowiska przyrodniczego, osiągnięcia techniki i potrzeby trwałego (zrównoważonego) rozwoju mogły być harmonizowane i osiągane. A. Drapella-Hermansdorfer wskazuje na sprawdzoną praktykę uprawy krajobrazu w duchu angielskim, która opiera się na łączeniu „użyteczności z estetyką" (Drapella-Hemrnadorfer 2014: 35). Współcześni pionierzy kierunków środowiskowych w projektowaniu wskazują na pojęcie krajobrazu pracującego (working landscape), mające mocne podstawy ekonomiczne m.in. w zakresie funkcji i różnorodności usług ekosystemów. Uwzględnia się także ich rozmaite korzyści i funkcje trudne do zastąpienia za pomocą technicznych środków w przypadku nieodwracalnego zniszczenia ekosystemów. Wycena usług ekosystemów stanowi argument za ochroną terenów cennych przyrodniczo, dotychczasowym sposobem ich uprawy oraz impuls do przeprowadzenia zabiegów renaturyzacji tam, gdzie to konieczne. Na przykład odtwarzania terenów zalewowych wzdłuż cieków w miastach, odbudowy naturalnych zbiorowisk roślinnych (np. łęgowych), stworzenia mniejszych zbiorników gromadzących i podczyszczających zebrane wody opadowe z okolicy. Jednym z głównych zagadnień funkcjonowania krajobrazu jest odtwarzanie i planowanie połączeń ekologicznych pomiędzy terenami zieleni w mieście. Integralnym elementem sieci korytarzy ekologicznych mogą być nowe parki, szczególnie w układzie linearnym, tworzące szlaki piesze, rowerowe oraz 
ścieżki tematyczne. W przypadku ich powodzenia można je popularyzować i wdrażać w innych częściach miasta, także jako uzupełnienie zespołów osiedli mieszkaniowych, przebudowy uregulowanych cieków, przekształcenia nieużytków urbanistycznych na nowe parki, dostępne dla mieszkańców.

Wiele wymienionych przez Ojca Świętego prośrodowiskowych propozycji rozwiązań, innowacji, alternatywnych kierunków rozwoju dla miast znajduje swoje potwierdzenie w nowych przedsięwzięciach inicjowanych w Europie i na świecie. Przykładem mogą być udane próby renaturalizacji zdegradowanego krajobrazu miejskiego i zakładania w ich miejscu przestrzeni publicznych (parków). Wokół tych przedsięwzięć często tworzą się oddolne inicjatywy lokalnych społeczności partycypujące w ich zakładaniu, ochronie, edukacji ekologicznej. Część projektów architektury krajobrazu dotyczy kreowania ogólnodostępnych terenów zieleni w miastach często na nieurządzonych, nieuporządkowanych enklawach zieleni, w tym zagrożonych dzisiaj zewsząd terenów cennych przyrodniczo. Znajduje to uzasadnienie nawet w przypadku dużych miast i aglomeracji, gdzie odczuwalny jest deficyt terenów zieleni publicznej, a pozostałości niezurbanizowanych obszarów kurczą się na skutek procesów inwestycyjnych i urbanizacji, przez co kontakt mieszkańców z przyrodą na co dzień jest utrudniony albo wręcz niemożliwy.

W Polsce nie dzieje się pod tym względem najlepiej. Jedną z barier jest brak systemowego podejścia do terenów zieleni w mieście (określanego w literaturze pojęciem zielonej infrastruktury), czyli kształtowania terenów zieleni połączonych siecią ekologicznych powiązań i korytarzy. Brakuje także strategii, wymogów i zachęt dla przedsiębiorców inwestycyjnych do przeprowadzania kompleksowych kompensacji w środowisku przyrodniczym. Procesom urbanizacji i rozrostowi miast w niedostatecznym stopniu towarzyszy aktywna polityka rozwoju nowych terenów zieleni, standardów ich utrzymania i ochrony krajobrazu. Zagadnieniem przyszłościowym jest polityka odzyskiwania terenów poprzemysłowych na cele społeczne i ekologiczne według najlepszych światowych wzorców w zagospodarowaniu przestrzeni typu brownfields. Potencjał przyrodniczy polskich miast, choć wciąż wyróżnia je spośród innych ośrodków miejskich w Europie, jest zagrożony, źle chroniony i niewykorzystany społecznie.

\section{Wnioski}

Papież Franciszek, opisując złożone kwestie ekologiczne w świetle ekologii integralnej, pyta o przyczyny negatywnych zjawisk i procesów oraz proponuje alternatywne kierunki do rozwijania. Wiele z przedstawionych w Luadato si' postulatów znajduje praktyczne potwierdzenie w całej grupie rozwiązań projektowych w miastach europejskich i na świecie. Rolą architektury krajobrazu jest także przełożenie postulatów i propozycji zmian na język konkretnych decyzji planistycznych i projektowych. Kongijian Yu, jeden z najwybitniejszych przedstawicieli współczesnej architektury krajobrazu, nazywany chińskim Olmstedem, stwierdza, że architektura krajobrazu jest dzisiaj przede wszystkim sztuką przetrwania (dosł. art. of survival), a nie sztuką ozdobnego ornamentu. W miastach istnieje potrzeba stworzenia sieci drobnych i większych obiektów istotnych dla funkcjonowania krajobrazu i zachowania różnorodności biologicznej, gdzie edukacja ekologiczna może być z powodzeniem realizowana z wykorzystaniem współczesnych osiągnięć techniki. Ochrona przyrody, jeżeli ma być skuteczna, musi w coraz większym stopniu uwzględniać aspekty nie tylko przyrodnicze, ale i społeczne, w tym potrzebę kontaktu z przyrodą na co dzień - w mieście (nie okazjonalnie - w oddaleniu od dużych ośrodków miejskich), przybliżenia słabo poznanych elementów przyrodniczych oraz procesów przyrodniczych, zachęty woluntarystycznego zaangażowania w ochronę przyrody w skali lokalnej i globalnej. Jak pokazują doświadczenia miast zachodnioeuropejskich, wokół osiedlowych parków ekologicznych, lokalnych terenów 
chronionych organizują się wspólnoty i grupy działania partycypujące w przedsięwzięciach ochronnych i popularyzatorskich.

\section{Bibliografia}

Böhm A., Zachariasz A. 2005. Architektura krajobrazu i sztuka ogrodowa. Ilustrowany stownik angielsko-polski. Warszawa: Krajowy Ośrodek Badań i Dokumentacji Zabytków.

Douglas I., James P. 2015. Urban Ecology: An introduction. London-New York: Routledge Taylor \& Francis Group.

Drapella-Hermansdorfer A. 2014. Plany krajobrazowe i zarządzanie zieloną infrastrukturą miasta. W A. Pancewicz (red.). Zielona infrastruktura miasta, 31-58. Gliwice: Wydawnictwo Politechniki Śląskiej.

France R.L. 2012. From Barn Elms reservoirs to the London Wetland Centre. W R.L. France (ed.), Environmental Restoration and Design for Recreation and Ecotourism. Integrative Studies in Water Man-agement and Land Development, CRC Press, 125-212.

Franciszek (papież). 2013. Adhortacja apostolska Evangeliigaudium, https://w2.vatican.va/content/ francesco/pl/apost_exhortations/documents/papa-francesco_esortazione-ap_20131124_evangeliigaudium.html (dostęp: 20.06.2016).

Franciszek (papież). 2015. Encyklika Laudato si'. W trosce o wspólny dom. Kraków: Wydawnictwo M.
Hopkins J., Neal P. 2013. The Making of the Queen Elisabeth Olympic Park. John Wiley \& Sons Ltd. Jakubowski K. 2015a. „Edukacja w miastach”, Zieleń Miejska 10: 34-36.

Jakubowski K. 2013a. Niekonwencjonalne formy współpracy międzysektorowej w kształtowaniu zieleni miejskiej na przykładzie Londynu. W T. Bergier, J. Kronenberg, P. Lisicki (red.). Zrównoważony rozwój - Zastosowania. Poradnik Przyroda w mieście - rozwiazania, t. 4, 87-97. Kraków: Fundacja Sendzimira.

Jakubowski K. 2015b. „«Piękno nieoczywiste». Rola miejskich nieużytków w kształtowaniu nowej kategorii parków miejskich". Przestrzeń i Forma 24: $145-162$.

Jakubowski K. 2016a. Ekologia miasta w perspektywie Laudato si'. W J. Poznański, S. Jaromi (red.). Kościót i nauka w obliczu ekologicznych wyzwań. Źródta, inspiracje i konteksty encykliki „Laudato Si'”. Kraków: Wydawnictwo WAM.

Jakubowski K. 2016b. „Ochrona przyrody przez udostępnienie". Zieleń Miejska 5: 38-40.

Pawlaczyk P., Jermaszek A. 2009. Poradnik lokalnej ochrony przyrody (wyd. 4 zmienione). Świebodzin: Wydawnictwo Klubu Przyrodników.

Zachariasz A. 2014. O kształtowaniu systemów terenów zieleni miejskiej w kontekście zielonej infrastruktury ze szczególnym uwzględnieniem Krakowa. W A. Pacewicz (red.), Zielona infrastruktura miasta, 59-88. Gliwice: Wydawnictwo Politechniki Śląskiej.

\section{Inspirations from Laudato Si' for Landscape Architecture Design in Cities}

\section{Abstract}

This paper presents an original study on the encyclical Laudato Si' (LS) in the context of environmental problems of modern cities and contemporary landscape architecture. The Holy Father's encyclical provides an inspiring diagnosis and description of the contemporary phenomena which draws on the achievements and findings of various fields of research. In the paper, the author formulates ten themes based on LS in the light of cities' sustainable development and landscape architecture design. The Pope points out the interdependence between the natural environment and society. A detailed analysis shows that the overtone of the conclusions contained in the document is rather positive: there are other possible scenarios for the urban development and new standards for shaping (or, where necessary, restoring) the urban environment. The author analyses proposals of changes and practical solutions providing inspiration for social, environmental and spatial renewal of modern cities. The author analyses them in the context of contemporary achievements in landscape architecture where one of the most important prospects and future topics is urban landscape restoration.

\section{Keywords}

urban park, ecosystem services, biodiversity, access to nature, landscape restoration 